\title{
The Role of Learning in Forming Students Career Choices of Islamic Economics Major
}

\author{
Abdul Latif ${ }^{1}$, Azidni Rofiqo², Muhammad Alfan Rumasukun ${ }^{3}$, Iqbal 'Imari ${ }^{4}$, M. Qoshid Al \\ Hadi $^{5}$ \\ \{abdullatif@unida.gontor.ac.id ${ }^{1}$,rofiqozidni@gmail.com² \\ alfanrumasukun@unida.gontor.ac.id ${ }^{3}$ \} \\ University of Darussalam Gontor ${ }^{1,2,3,4,5}$
}

\begin{abstract}
This research is based on the researcher's anxiety that Islamic banking is dominated by non-graduate of Islamic Economics Study. This research aims to determine the factors that influence graduate of Islamic Economics Study perception for career selection and determine the dominant factors that influence graduate of Islamic Economics Study perception for career selection. The research is a quantitative research by using survey method in collecting data. The questionnaire distributed to 58 respondents who were graduated from Islamic Economics programs, University of Darussalam Gontor Ponorogo. The data analysis technique is the exploratory factor analysis. The results of analysis data show that there are three factors formed that influence the graduate of Islamic Economics Study perception for career selection namely consideration of labour market, work environment, and professional education. The most dominant factor that influences the perception of a graduate of Islamic Economics Study for career selection is the consideration of professional education.
\end{abstract}

Keywords: Graduated from Islamic Economics, Career Selection, Labor Market, Work Environment, Professional Education.

\section{Introduction}

Islamic economics has become an option for the development of the world economy. One indicator that can be seen is the increasing number of conventional banks which open Islamic banking services. The high growth of the Islamic finance industry requires the support of professional human resources. The Deputy Governor of Bank Indonesia, Muliaman D. Hadad, stated in the next 4-5 years, around 40,000 workers are required to work correctly in Islamic banking. BRI Syariah's Managing Director, Ventje Rahardjo, stated the need for sharia banking human resources is estimated to reach 45,000 in 2018. The need for HR will increase by the increasing number of sharia banking units, including micro banking which develope in the regions. So far, HR in Islamic banking is still dominated by graduates from non-Islamic backgrounds[1]. The development of Islamic banking in Indonesia in the past decade has been very rapid. It can be seen from the growth and the development of the Islamic banking industry in this country, and the increased level of public trust. Although the total assets of new sharia banks amounted to $3.39 \%$ of the total assets of national banks, the prospect of sharia banking in the future was very bright, especially considering to the enormous market share, so it is natural for many conventional banks to open sharia branches directly or convert its conventional branches into sharia branches [2]. 
Also, the Islamic banks balanced growth is followed by the need for an increasing number of workers. It aims to provide excellent service for consumers and education of Islamic banking products. However, there are several problems in human resources. According to Permana, one of the biggest problems in sharia human resources is the banks have difficulty to find the competent and capable sharia banking HR. Islamic banking tends to take human resources outside Islamic universities because human resources in Islamic banks are usually more accessible given knowledge about Islamic banking. Bank Indonesia projects the Islamic banking industry can have a market share of 15 per cent in the next ten years if it can experience stable growth like in the past few years. Bank Indonesia (BI) Deputy Governor's Halim Alamsyah, a member of the Financial Services Authority (OJK), said the Islamic banking industry had grown at an average of 40.5 per cent per year, in the past half decade. This growth is twice faster than conventional banking, so it's market share has continued to increase in recent years. But today, market share (based on its assets) is still around 4 per cent [3].

Therefore, based on the background, the formulation of the problems in this study are: what are the factors influence some graduate Islamic Economics Study in choosing their carrier, what is the most dominant factor that influences some graduate Islamic Economics Study in choosing their carrier. In this paper, these questions will be answered and will be found the solution for it.

\section{Literature Review}

Social Cognitive Career Theory (SCCT) was developed as a way to explain career development through a focus on socio-cognitive construction [4]. Based on Bandura's [5] social cognitive theory, the SCCT reveals how career and academic interests mature, how career choices are developed, and how these choices turn into action. It is achieved through three main principles, namely self-efficacy, expected results, and goals [4]. According to Bandura, self-efficacy can be grown and learned through four sources of information, namely, (1) enactive mastery experience; (2) vicarious experience; (3) verbal persuasion; and (4) physiological and affective states, individuals with high self-efficacy in career decision making will succeed in making career decisions that are right for themselves[6]. Cognitive Social Career Theory provides a theoretical framework for understanding vocational interests and decision-making processes [7]. The essence of SCCT is the concept given by someone that contributes to career-related learning experiences [8].

Thomson et al., this finding indicates the importance of social status perceived as a predictor of various types of career-related learning experiences which then form self-efficacy, expectations of results to be obtained, and one's interests in certain RIASEC [8]. Ali, the results showed that entrepreneurship education, entrepreneurial experience and social entrepreneurial attitudes were positively related to the desire (students after Nigerian students at UUM) to work alone [9]. This research contributes enriched with knowledge and significant implications for the theory and application of entrepreneurship. Navarro et al., this study is an SCCT model and shows that some modifications might be needed so that the SCCT can be fully applied in the lives of middle school students in Mexico America. Through the use of theories that highlight and explain sociopolitical, sociophonetic, and cultural factors, counselling psychologists can intervene in this intergenerational cycle and help Mexican Americans survive and succeed in their education and careers [10]. 
Zikic and Saks, a social cognitive theory is used to explain the relationship between activities that are relevant to a career. The results of this study provide practical information about what job seekers can do to improve their job search clarity and job search efficacy and show the application of social cognitive theory to understand and predict job search behaviour [11]. Cunningham et al., social cognitive career theory is used to investigate the background of students entering the sports and recreation industry. The research results show that selfefficacy and outcome are positive relationships with vocational interests, which in turn are positively related to career choice goals [12]. Al-Mansor, this study has examined the theory of career success such as Social Cognitive Career Theory (SCCT), the SCCT Advanced Model, the Practice Behavior Model, and the Integrated Career Success Model. Based on the theory, this study has predicted several individual factors (such as human capital, individual personality, and social capital) and contextual factors (such as organizational and individual environmental support) in influencing the success of an academic career [13].

From the literature review can be obtained the following hypothesis:

$\mathrm{H} 1$ = LM has positive effects on PGIE

$\mathrm{H} 2=$ WE have a positive effect on PGIE

$\mathrm{H} 3=\mathrm{PE}$ has a positive effect on PGIE

\section{Materials and Methods}

This research is quantitative research, and research location is the University of Darussalam Gontor especially on the study of the Islamic Economic University of Darussalam Gontor. The object of this research is the perception of career selection of Islamic Economics program at the University of Darussalam Gontor. The population in this study is a graduate of Islamic Economics program at the University of Darussalam Gontor. The data sources used in this study are primary data. Primary data is data obtained from the first source either from individuals or individuals, such as the results of filling out questionnaires which are answers from respondents. The analytical tool is multiple regression:

$\mathrm{PGIE}=\mathrm{a}+\beta_{1} \mathrm{LM}_{1}+\beta_{2} \mathrm{WE}_{2}+\beta_{3} \mathrm{PE}_{3}+\mathrm{E}$.

\section{Result and Discussion}

\subsection{The Results Of The Classical Assumption Test (Normality)}

Table 1. Table of Normality

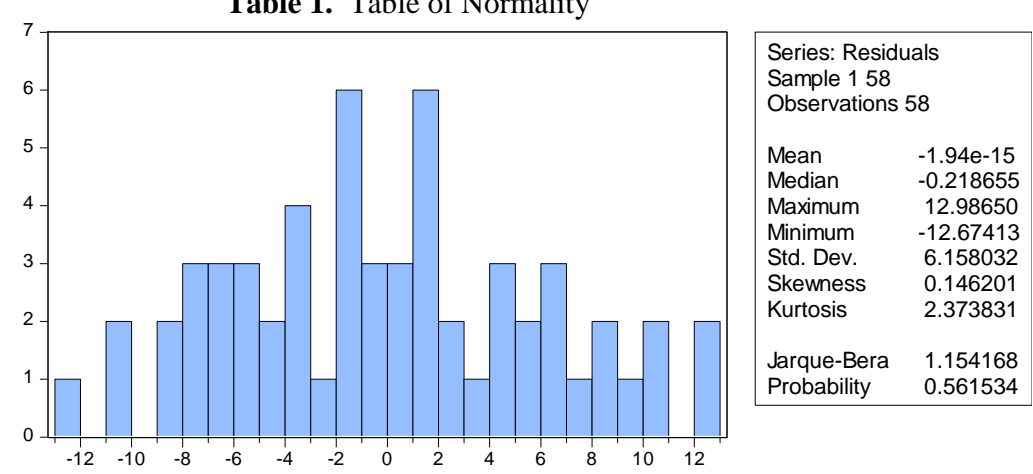


Looking at the results of the data with tools Eviews 9 can be known probability value JarqueBera $0,561534>0,05$. It can be concluded that the residuals are normally distributed.

\subsection{The Classical Assumption Test (Auto-Correlation)}

To test whether or not autocorrelation researchers used LM Test (Breusch-Godfrey) results:

Table 2. Table of Autocorrelation

Breusch-Godfrey Serial Correlation LM Test:

\begin{tabular}{llll}
\hline \hline F-statistic & 1.722530 & Prob. F(2,34) & 0.0792 \\
Obs*R-squared & 29.19090 & Prob. Chi-Square(2) & 0.0841 \\
\hline \hline
\end{tabular}

By looking at Chi-Square (2) obtained a value of $0.841>0,05$ it can be concluded that this model does not have the autocorrelation.

4.3. The Classical Assumption Test (Heteroskedasitas)

The result of heteroscedasticity test using Heteroskedasticity Test:

Table 3. Table of Autocorrelation

Heteroskedasticity Test: Breusch-Pagan-Godfrey

\begin{tabular}{llll}
\hline \hline F-statistic & 0.109980 & Prob. F(3,54) & 0.9539 \\
Obs*R-squared & 0.352228 & Prob. Chi-Square(3) & 0.9499 \\
Scaled explained SS & 0.209729 & Prob. Chi-Square(3) & 0.9760 \\
\hline \hline
\end{tabular}

By looking at Obs * R-squared 29.5475 with Prob. Chi-Square $0.9499>0.05$ then means a homoskedastic model with a 5\% significance level; in other words, the estimated model does not contain heteroscedasticity.

4.4. Interpretation Of Coefficient Of Determination, Regression Coefficient And F Test The coefficient of determination is used to measure how far the ability of the model in explaining the variation of the dependent variable. The results of the data if using tools Eviews 9 as follows:

Table 4. Table of Autoregression

Dependent Variable: Y

Method: Least Squares

Date: 02/24/19 Time: 15:02

Sample (adjusted): 158

Included observations: 58 after adjustments

\begin{tabular}{ccccc}
\hline \hline Variable & Coefficient & Std. Error & t-Statistic & Prob. \\
\hline \hline C & 6.792575 & 5.753586 & 1.180581 & 0.2429 \\
LM & 0.219840 & 0.111527 & 1.971191 & 0.0438 \\
WE & 0.255348 & 0.100573 & 2.538935 & 0.0140 \\
PE & 0.624663 & 0.199890 & 3.125040 & 0.0029
\end{tabular}




\begin{tabular}{lrll}
\hline \hline R-squared & 0.235435 & Mean dependent var & 23.25862 \\
Adjusted R-squared & 0.192959 & S.D. dependent var & 7.042628 \\
S.E. of regression & 6.326776 & Akaike info criterion & 6.593931 \\
Sum squared resid & 2161.517 & Schwarz criterion & 6.736030 \\
Log-likelihood & -187.2240 & Hannan-Quinn criter. & 6.649281 \\
F-statistic & 5.542800 & Durbin-Watson stat & 1.100523 \\
Prob(F-statistic) & 0.002165 & & \\
\hline \hline
\end{tabular}

Based on the results of this study shows that the value of Adjusted R squared coefficient of 0.192959 or $19,3 \%$. It shows that $19,3 \%$ Preference is influenced by independent variables $=$ labour market, work environment, professional education while the rest of $80,7 \%$ is explained by other variables that are not in this study.

Regression coefficient (T-Test). This study uses multiple regression analysis. This analysis is used to measure the strength of two or more variables and also shows the direction of the relationship between the dependent variable with the independent variable. Based on the t-test, the decision is as follows:

Tests on Labor Market. The first hypothesis states that the labour market has a positive effect on the perception of a graduate of Islamic Economics. Based on the results obtained that the significance value $0.0438<0.05$. It means that $\mathrm{H} 0$ is rejected and $\mathrm{H} 1$ cannot be rejected. It means the labour market has a positive effect on the perception of a graduate of Islamic Economics.

Tests on Work Environment. The second hypothesis states work environment has a positive effect on the perception of a graduate of Islamic Economics. Based on the results obtained that the significance value $0.0140<0.05$. It means that $\mathrm{H} 0$ is rejected and $\mathrm{H} 2$ cannot be rejected. It means the work environment has a positive effect on the perception of a graduate of Islamic Economics.

Tests on Professional Education. The second hypothesis states professional education has a positive effect on the perception of a graduate of Islamic Economics. Based on the results obtained that the significance value $0.0029<0.05$. It means that $\mathrm{H} 0$ is rejected and $\mathrm{H} 3$ cannot be rejected. It means professional education has a positive effect on the perception of a graduate of Islamic Economics.

Based on the test results with multiple linear regression method, to test the influence of independent variables on the dependent variable, it can be compiled an equation as follows: $\mathrm{PGIE}=6.792575+0.219840 \mathrm{LM}+0.255348 \mathrm{WE}+0.624663 \mathrm{PE}+\mathrm{e}$

- The LM regression coefficient is 0.219840 which means that every $1 \%$ increase of LM will increase PGIE by $00.219840 \%$ assuming another variable is constant and vice versa.

- The WE regression coefficient is 0.255348 which means that every $1 \%$ increase of WE will increase PGIE by $0.255348 \%$ assuming another variable is constant and vice versa.

- The PE regression coefficient is 0.624663 which means that every $1 \%$ increase of PE will increase PGIE by $0.624663 \%$ assuming another variable is constant and vice versa. 
Regression Coefficient (F-Test). F-test hypothesis testing is used to see whether at least one independent variable influences the dependent variable. Or it works to see if the variable matches the model from the F-test results obtained 5.542800 with a significance level of 0.05 . Thus the results of the analysis in this study indicate that at least one independent variable affects the PGIE, or the model according to the variable.

\subsection{Discussion}

The education system in the University of Darussalam Gontor is unique. It is Islamic boarding university system that organizes all academic and non-academic activities integrated inside the campus. All students activities are held and integrated on campus because all students must stay in the dormitories provided by the university.

Islamic Economic study as one of the undergraduate programs offered by University of Darussalam Gontor also run several planned programs in every semester inside the campus and integrated. Based on the program vision, namely to be an excellent undergraduate program in Islamic Economics science development that integrated with the Islamic boarding university in 2030.

After finishing college, several numbers of a graduate of Islamic Economics program of the University of Darussalam Gontor are accepted well in labour market and work environment that conforms with their academical knowledge such as in Islamic Banking, insurance, trainers, etc. And several others are trying to get jobs in different fields.

However, the choice they made to have a bright carrier in the future are influenced by the available labour market, work environment and professional education previously.

\section{Conclusion}

This study concludes that there are three factors formed that influence the graduate of Islamic Economics Study perception for career selection namely consideration of labour market, work environment, and professional education. The most dominant factor that influences the perception of a graduate of Islamic Economics Study for career selection is the consideration of professional education.

Acknowledgements. This paper was presented in the International Conference on Business, Law, and Pedagogy 2019. We thank the University of Darussalam for fully funding of paper presented at that conference.

\section{References}

[1] E. a. Ardiansyah, "Kontruksi Kopentensi Profesional Sajrana Ekonomi Syari'ah pada Lembaga Keuangan Syari’ah,” J. Penelit. Sos. Keagamaan, vol. 07, no. 01, 2013.

[2] S. Rusydiana, "Analisis Masalah Pengembangan Perbankan Syariah di Indonesia: Aplikasi Metode Analytic Network Process," Bisnis dan Manaj., vol. 06, no. 02, 2016.

[3] Azmy, "mengembangkan human resource management yang strategis untuk menunjang daya saing organisasi: perspektif manajemen kinerja (performance management) di bank syariah," J. binus Bus. Rev., vol. 06, no. 01, 2015.

[4] S. D. Lent, Hackett, Gail, Robert W, Brown, "Toward a Unifying Social Cognitive Theory of Career and Academic Interest, Choice, and Performance," J. Vocat. Behav., vol. 45, no. 1, August 1994, 1994. 
[5] A. Bandura, "The explanatory and predictive scope of self-efficacy theory," J. Clin. Soc. Psychol., vol. 4, pp. 359-373, 1986.

[6] Bandura Albert, "Social cognitive theory of self-regulation," Organ. Behav. Hum. Decis. Process., vol. 50, no. 2, pp. 248-287, 1991.

[7] G. Hackett, R. W. Lent, and S. D. Brown, "Contextual supports and barriers to career choice: A social cognitive analysis.,” J. Couns. Psychol., vol. 47, no. 1, pp. 36-49, 2000.

[8] M. N. Thompson and J. J. Dahling, "Perceived social status and learning experiences in Social Cognitive Career Theory," J. Vocat. Behav., vol. 80, no. 2, pp. 351-361, 2012.

[9] Ali, "No TitFactors Influencing Self-Employment Intention Among Nigerianle," 2014.

[10] R. L. Navarro, Rachel L., Flores, Lisa Y., Worthington, "Mexican American middle school students' goal intentions in mathematics and science: A test of social cognitive career theory,” J. Couns. Psychol. Vol 54(3), Jul 2007, 320-335, vol. 54, no. July, 2007.

[11] A. M. Zikic, J., Saks, "Job search and social cognitive theory: The role of careerrelevant activities,” J. Vocat. Behav., vol. 74, 2009.

[12] J. S. Cunningham, G. B., Bruening, J., Sartore, M. L., Sagas, M., \& Fink, "Career Choices," J. Career Dev., vol. 32, no. 2, 2005.

[13] \& R. M. R. Al-Mansor Abu Said, "Tinjauan Faktor-faktor Pendorong Kejayaan Kerjaya Ahli Akademik : Konteks Universiti Penyelidikan di Malaysia," Sosiohumanika, vol. 5, no. 2, 2012. 